\title{
Reconciliation: a gift from God
}

\author{
M Masango \\ (University of Pretoria)
}

\section{ABSTRACT}

\section{Reconciliation: a gift from God}

This article analyses the work of reconciliation based on Prof $P$ Meiring, especially his work with the Truth and Reconciliation Commission. The article takes seriously the theological aspect of reconciliation that leads to peace. This ritual is helpful in making sure that victims hear the stories of how their beloved were killed in Apartheid times. The TRC thus created a space where victims of injustices could have a privilege of meeting with perpetrators, in a way of reconciliation. It finally looks at the suffering experienced by them and the response by government.

\section{INTRODUCTION}

\subsection{Reconciliation an introduction}

Reconciliation is a familiar word for most people in South Africa; because as the new democracy dawned upon us, we embarked on a process through the Truth and Reconciliation Commission (TRC). Madiba knew that the country needed healing. As a nation we were forced by circumstances of violence to deal with the legacy of Apartheid by means of the TRC. The commission was set up in order to promote unity and reconciliation in a spirit of understanding which transcended the conflict and divisions of the past. This ideal was shared by Archbishop Tutu (who was chairperson of TRC). On 16 December 1995 he said the following words which launched the process of reconciliation.

Reconciliation is absolutely central to our concern in the work of our commission in helping our land and people to achieve genuine, real and not cheap and spurious reconciliation..... we are meant to be a part of the process of the healing of our nation, of our people, all of us, since every South African has to some extent or other been traumatised. We are wounded people because of the 
conflict of the past, no matter on which side we stood. We all stand in need of healing ${ }^{1}$.

The above words remind the author of the story shared by Mbiti about war. Mbiti shared a ritual that soldiers had to undergo after fighting another tribe. He says:

All the soldiers had to sleep outside a village for a night and after war and the following day a spiritual healer will come and wash their spears at the river. He will also perform a ritual of releasing their anger. Then they were allowed to come into the village (Mbiti 1975:145).

In other words, the army had to cool off their anger across the river by sleeping outside the village, and after a ritual had been performed the following day, they would enter the village with all those who are captured, animals, cattle, sheep, goats etcetera. In this way they would not bring the spirit of anger and fighting into their homes. In short, they had to be reconciled with those who remained at home, the land and their own tribe. The reader will understand the process that led Nelson Mandela to launch reconciling as a way of healing South Africans in order to start a new nation based on peace. Mbeki was right when he said:

Our assessment of the TRC's success cannot ... be based on whether it has brought contrition and forgiveness, or whether at the end of its work, it handed us a united and reconciled society. For this was not its mandate. What the TRC set out to do, and has undoubtedly achieved, is to offer us the signposts in the long march to those ideals. We have now been challenged to live a life which will help us build a new nation ${ }^{2}$.

The TRC was seen as a ritual of cleansing as well as an important contributor to the achievement of reconciling and preparing the nation (black and white) to live and face together their new democracy. It was a way of challenging people in launching national unity, national reconciliation and national reconstruction. The reader

\footnotetext{
1 Archbishop's first words when he launched the Truth and reconciliation Commission.

2 Mbeki: sharing of the TRC report on April 15, 2003. http://www. polity.org.za
} 
will now understand why our journey of national building starts with cleansing, namely TRC reconciliation - the word reconciliation is connected to healing. The letter of 1Corintians 12 reminds us of the gifts of the Spirit given to every person by God.

8. To each is given through the Spirit the utterance of wisdom and to another the utterances of knowledge according to the same Spirit.

9. To another faith by the same Spirit, to another a gift of healing (reconciliation) by the Spirit.

10. To another the working of miracles, to another prophecy, to another the ability to distinguish between spirits... (1 Cor 12:8-10).

The above gifts are given in order to exercise ministry among God's broken people. Piet Meiring is gifted in the area of reconciliation that leads people to unity. As a result of this gift people are able to live in peace. One could ask what reconciliation is. The word to "reconcile" derives from two Latin words (re and conciliare) that together render the meaning to "unite". As we acknowledge ourselves and others as to who we truly are, we further realise the prayer of our Lord when he said:

"Father that may all be one; even as thou, Father art in me and I in thee, that they also may be in us, so that the world may believe that thou hast sent me" (John 17:21) ${ }^{2}$.

The issue of unity and reconciliation is extremely important in the scriptures. In our case reconciliation denotes the following things according to Gurnick.

1. To cause to be friendly again;

2. to adjust, settle (as to reconcile differences);

3. to make consistent or congruous and;

4. to bring to acquiesce (as to reconcile oneself to affliction) (Gurnick 1973:476).

The above quotation reminds us that, when we reconcile, we unite ourselves as well as other people. Schreiter uses the phrase concept. This concept is better and sees reconciliation of the self in different way. He says: "The self settles into the self through reconciliation through reconciliation" (1992:53). In other words, before we can reconcile ourselves with others, including God, we must first 
reconcile ourselves with our self. Therefore, in terms of South Africa (past) with its Apartheid and discriminatory laws, we need to be in touch with our selves in order to embark on reconciliation especially with those who have hurt us. We need to love ourselves before we can love others. It is within this framework that we must approach this topic of reconciliation. In this way we will be able to enter the process of confessing our sins, and then learn to forgive others. People are familiar with the phrase, "To err is human to forgive is divine”. At this juncture we will learn what forgiveness is, as well as how to forgive.

\subsection{The process of reconciliation}

The word reconciliation suggests that something has gone wrong within the system or nation, hence the need for reconciliation. It also assumes that there is conflict either between two people, nations or groups who are in relationships marked by tension. Paul shares some insights about this word in the second letter to the Corintians, chapter 5 . He says:

17: Therefore, if anyone is in Christ, he is a new creation, the old has passed away, behold, the new has come.

18: All this is from God, who through Christ reconciled us to himself and gave us the ministry of reconciliation;

19: ...That is, in Christ God was reconciling the world to himself, not counting their trespasses against them, and entrusting to us the message of reconciliation.

20: So we are ambassadors for Christ, God making his appeal through us. We beseech you on the behalf of Christ, to be reconciled to God” (2 Cor 5:16-19).

Continueing with this concept we need to be aware that the word reconciliation or reconcile means a change from a state of enmity to the one of friendship. In other words, it challenges us to relate with those we were indifferent towards. As we embark on this concept a radical change occurs in which an intimate and personal relationship is renewed or repaired. The process leads or affords us an opportunity to begin the difficult process of coming to terms or grapple with atrocities of the past. In terms of the South African process of reconciliation, it creates an opening for people to face victims and perpetrators in order to work on their past conflicts or 
violations. Guma and Milton suggest a way forward on reconciliation. They say:

If we are going to be successful in making up a process of reconciliation, we have to be more and more aware of movements to expose people to what other people are doing. The matter of rebuilding the nation should not be looked at by government only but is a matter for all people of South Africa” (Guma and Milton 1997:18).

All are invited to explore the issue of conflict which developed as a result of Apartheid. It also appears that things were different before. Following the idea of reconciliation Martin (1981:30) suggests that "There was a real friendship, first existing between people, then it was broken and finally it needed to be restored.

The reader can clearly understand that reconciliation is our greatest challenge in the twenty first century. Hacker further says that "reconciliation at its core is a process of transformation for both sides in a conflict situation". He continues to say that "transformation therefore is critical to an effective multicultural society and a strategy of change is therefore needed” (Hacker, 1992:30).

The above process describes part of Prof Meiring's life in the TRC. Through his leadership he was able to recognise, understand and appreciate his own Afrikaner culture which oppressed others. He had to come to terms with his own past through confessing his own sins. As a result of the above, change became part of his life. Through reconciliation Piet was able to see the impact of differences between race, gender, class age, religion, physical ability and language in depth. Hence he was able to rise above his own race in order to serve the country through the TRC. His main concern was to rebuild people, especially those who were abused and violated. The words of Paulo Freire (in Goodman 2001) are worth quoting. He says:

Humanization is the vocation of human beings, as oppressors dehumanize others and violate their (the oppressed) rights they themselves also become dehumanized.

Freire further says:

Dehumanization which marks not only that humanity has been stolen but also (though in a different way) those 
who have stolen it are a distortion of becoming more fully human

(Goodman, 2001:122).

Mandela on the other hand adds to this interesting concept words that challenge those who violate and oppress others. He says:

I knew as well as I knew anything that the oppressor must be liberated just as surely as the oppressed. A man (sic) who takes prisoner of hatred locked behind the bars of prejudice and narrow mindedness.

Mandela (1994:88) continued saying

I am not truly free if I am taking away someone else's freedom, just as surely as am not free when my freedom is taken away from me. The oppressed and the oppressor alike are robbed of humanity.

Through these words the reader can understand the concept and aim of reconciliation. The focus of it is to help people deal with the root cause of hostility and unjust laws that ruled for so many years in our country. Martin Luther King Jr shares an important aspect that challenges South Africans to continue working on reconciliation, especially these days when we face xenophobia. King (1981:7) says:

I can never be what I ought to be until you are what you ought to be, and you can never be what you might be until I am what I ought to be.

True reconciliation occurs or happens only if people are aware of the dynamics between the oppressed and oppressor, or the conflict that divides them. This process will help both to work and focus on the dehumanisation that operates within the two. Reconciliation leads people who are in conflict to recognise the significance of their evil deeds, and we cannot take it lightly. In other words, God does not wink at our cruelty and injustice. Through the cross God confronts us to face these injustices. The cross shows us that reconciliation is costly to God. It is not that God demands that someone else pay. On the contrary it is this loving God who in Christ our Lord offers reconciliation and bears the cost of our refusal. This once and for all act is done by God through Christ who becomes the brother of those who suffer injustices and humiliation - and thus the atonement for our guilt and sin.

Moltmann (1994:40) speaks of "a God, who suffers vicariously for our sins bearing human guilt”. Through this act God then 
transforms the world through his own suffering. Reconciliation therefore can happen only when all parties understand each other in the ways that lead to behaving differently. In other words, reconciliation requires acknowledging the historic and continuing impact of racial privilege as well as working with the "targets" of those who misuse the power and its imbalances in order to effect reconciliation at the personal, interpersonal, institutional and cultural levels. South Africa has been fortunate in having a role model in the person of Mandela's stature who challenged us to deal with the past atrocities in order to prepare for a bright future.

\subsection{Theology of Reconciliation}

We live in a violent world that constantly needs to be confronted with justice, peace and reconciliation, which will hopefully lead people to live in harmony. As people of God, we need to live in hope of a better future. Hope encourages people to find a way out in order to create a peaceful future. We are challenged by circumstances of abuse and violence in order to work for justice and create an atmosphere of peace. The next generation will reap the fruits of conflict, violence and hatred if we do not address these atrocities of the past. If we address injustice, our children will embrace the fruits of reconciliation that is life changing, thus transforming the world into a long lasting peace. Let me stress this point of peace which is raised by Paul few times in Scripture, especially when he talks about healing the divisions between Jews and gentiles, male and female, slave and free. If this process is achieved, an intimate and personal relationship will be renewed, and then we will be able to live in a peaceful atmosphere in South Africa. Webster's dictionary suggests the following about reconciliation: "Restored to friendship or harmony, settled, resolve differences or to cause to submit or accept" (Long \& Breker 2003:97).

When one analyses this word from Greek "kattallaso" one finds a suggestion of a real friendship, first existing, then broken as the relationship continues. Then the brokenness comes in and affects the relationship, which challenges people to work on it. When people work on their relationship, they finally restore it and start to live in harmony. When Paul uses this word he applies it to a spiritual dimension, while Martin adds to this thought the announcement of reconciliation which is expressed in personal terms. In Jesus' ministry, reconciliation is used in reconciling broken relationships among human beings set up with the person always in view (Martin 
(1989:130). The use of the word suggests that there were preexisting barriers in the relationships. In short, reconciliation signals the reconnecting of those who have parted company. South Africans have experienced broken relationships, which separated them through violence and abuse that existed during Apartheid days. The TRC created a space were problems of society were discussed and then helped some of them to work through these broken relationships. Stories were released and the journey of reconciliation began, thus introducing a new way of relating to each other in the new South Africa. Paul uses this word a few times in scripture, for example in 2 Corinthians 5:18-19; Colossians 1:20, 22, Romans 5:10-11 and Ephesians 2:16. He uses it in a most powerful way to express the meaning of life, death and resurrection of our Lord. For him the coming of the Lord into the world offers people such a powerful new opportunity of reconciliation with each other and with God. The following phrases when combined together offer the true meaning of reconciliation, of being put into a relationship with God and with each other:

(a) A radical change and transformation of a relationship;

(b) Final restoration to harmony among people who clashed.

The main focus of humanity is to be reconciled to God and to each other. Jesus becomes the centre of reconciliation. John 3:16 articulates this love and reconciliation well, through God who so loved the world and gave his only begotten son. Therefore, human beings are invited to respond to God's initiative in reaching out to our sinful state. Atonement is a critical process that brings us back to God through Jesus who reconciles us. Theologically, this demands a change of heart through confession, repentance and most importantly forgiveness. Douglas (2002:82) reminds us that:

Reconciliation calls us to join the other person in the difficult journey of developing a contrite heart, confessing in an accountable manner, and responsibly compensating, as far as possible, for the destruction caused by the violation.

Human beings are invited to respond to God's initiative in reaching out to us sinful creatures. Theology always highlights that we are worth reconciling, and thus creating peace with God and with each other (at-one-ment). This is how the Jews understood the concept of reconciliation with God. The Greeks used it as a way of describing 
the results of an individual who has been in opposition to the other, but through reconciliation they now become friends again. But they did not apply this concept to God (Worthington 2006:95). When Paul wrote about the concept of being reconciled to God, to the Greeks he was embracing a new concept. One could conclude by saying "reconciliation" through Jesus Christ was often a stumbling block to Jews and foolishness to gentiles (1Cor1:23). According to the Jewish Christians' concept the process of reconciliation begins when an individual accepts God's invitation to make things right. Every person according to Paul is in need of this peace with God and with fellow beings. Once we recognise that we are estranged from God, we then need to repent in order to be reconciled to God through Christ. This opens a door to face our fellow beings, people we are at loggerheads with. Colossians develops this concept of estrangement

with God and with each other (1:21-23). It finally offers a way we can be reconciled. In short, to be reconciled to God moves us from estrangement to friendship. This process is clearly described in Acts 9 (the road to Damascus); a radical change took place in Paul's life. All animosity and bitterness were removed by that experience. The TRC sought to do the same; hence it borrowed from the Roman Catholic model of penance, confession and absolution. One is aware of the language of "truth" and "reconciliation" which became a central focus in dealing with healing the nation. This process opened a space for victims to be heard; it also brought perpetrators face to face with their own sins. Silence and exclusion of the oppressed was brought to the surface, and their stories were heard publicly. They had to face reconciliation with those they violated.

\subsection{Paul}

When Paul was reconciled to God by facing his sins he became a new creature; the old ways of torturing Christians came to pass, and he cared for people he had previously hated. A radical change took place which reconciled him to God and his fellow human beings. He was never the same again, and thus followed the truth and was reconciled to it. A new order was introduced in his life. (It is the same with some South Africans.) One can understand why South Africans underwent such a radical change, and we moved away from being a dysfunctional society into a normal functioning country. The reader is reminded by Jesus words, when he said to Pilate: "The truth shall set you free”. De Young (1997:46) is right by saying: "Through 
a process of casting off the dysfunction in our emotions, spirit, psych and relationships a person becomes healthy”.

The author is convinced that the process begins with God; and then it strengthens a person to live as a new creature even though in certain circumstances our environment and world (violence abuse) often do not change. Reconciliation is an issue that needs to be addressed all the time.

\subsection{CONCLUSION}

The ministries of reconciliation seek people to focus on the truth. This process will help perpetrators of crimes to face the pain they caused to others. We cannot avoid the violation we have caused others. This process will help them to become morally responsible citizens. The process must also not ignore survivors (victims) in sharing their own pain and violation caused by the other. They should be allowed to share their stories and in doing so, the process helps them to deal with their own hurts, anger and their own wounds which affect them during the time of their violation. When we continue through this process we then create a public space where we will engage each other in truth. The reader will now understand the role the TRC played with leaders such as Prof Meiring as they engage their own weaknesses. There was no way our country could have dealt with its ugly past, except through this ritual of cleansing that leads to healing. The TRC helped South Africans to pursue the truth, by focusing on lost stories of the lives of those who were oppressed. In other words, the stories of the beloved could have disappeared. Their stories would have disappeared from our history, and families would have not known the truth. The words of SACC general secretary still remain in my mind at the first hearing in East London. She said:

The commission for truth and reconciliation is not another Nuremberg trials. It turns its back on any desire for revenge. It presents an extraordinary act of generosity by a people who only insist that the truth and nothing else but the truth be told. The space is thereby created where the deeper process of forgiveness, confession, repentance, reparation, and reconciliation can take place.

(Quoted in Baum \& Wells 1997:28) 
The above issue continues to challenge South Africans and the global village. We are therefore asking to complete this process. It also calls us to the ministry of reconciliation and healing of those who are constantly violated in the world. Finally it challenges the whole world to get involved in the ministry of healing and reconciliation. It invites us to be ambassadors of healing and reconciliation. This process needs people who are committed to rebuild lives of people who are experiencing conflict and violence.

\section{Consulted literature}

Baum G \& Wells H 1997. Reconciliation, challenges to the churches. New York: Orbis books.

De Young, C P 1997. Reconciliation our greatest challenge, our only hope. Pennsylvia: Judson Press Valley Forge.

Douglas, I T (ed) 2002. Waging Reconciliation: God's mission in a time of globalization and crisis. New York: Church Publishing Inc.

Goodman, D J 2001. Promoting diversity and social justice: educating people from privileged groups. Thousand Oaks, C.A.: Sage Publishing

Guma, M \& Milton, L (eds) 1997. An African challenge to the churches in the twenty first century. Johannesburg: SACC Publications.

Gurnick, L 1973. Webster new collegiate dictionary. Springfield: G\&C Merriam Company.

Hacker, A 1992. Two nations, black and white separate, hostile, unequal. New York: University Press.

Long W J \& Breker P 2003. War and reconciliation, reason and emotion in conflict resolution. London: MIT Press.

King, M T 1981. Strength to love. Philadelphia: Fortress Press.

Mandela, N 1994. Long walk to freedom. The autobiography of Nelson Mandela. New York: Little and Brown.

Mbiti, J S 1975. Introduction to African religion. Nairobi: Heinemann Educational Books.

Martin, R P 1981. Reconciliation: A study of Paul's theology. Atlanta: John Knox Press.

Moltmann, J 1994. Jesus Christ for today's world. Minneapolis: Fortress Press.

Schreiter, R1992. Reconciliation, mission and ministry in a changing world order. New York: Orbis Books.

Worthington, E L 2006. Forgiveness and reconciliation: Theory and application. New York: Routledge, Taylor and Francis Group. 